\title{
Combined Effects of Citric Acid and Phytase Supplementation on Growth Performance, Nutrient Digestibility and Body Composition of Labeo rohita Fingerlings
}

\author{
Maryam Iqbal ${ }^{1,2, *}$, Muhammad Afzal ${ }^{2}$, Atif Yaqub ${ }^{1}$, Khalid Mahmood Anjum³, \\ Komal Tayyab ${ }^{2}$
}

${ }^{1}$ GC University, Department of Zoology, Fish Nutrition Laboratory, 54000, Lahore, Pakistan.

2University of Agriculture, Department of Zoology, Wildlife \& Fisheries, Fish Nutrition Laboratory, 38000, Faisalabad Pakistan.

${ }^{3}$ University of Veterinary and Animal Sciences, Department of Wildlife \& Ecology, 54000, Lahore Pakistan.

\section{How to cite}

Iqbal, M., Afzal, M., Yaqub, A., Anjum, K.M., Tayyab, K. (2022). Combined Effects of Citric Acid and Phytase Supplementation on Growth Performance, Nutrient Digestibility and Body Composition of Labeo rohita Fingerlings. Aquaculture Studies, 22(1), AQUAST656. http://doi.org/10.4194/ AQUAST656

\section{Article History}

Received 04 May 2021

Accepted 25 August 2021

First Online 25 August 2021

\section{Corresponding Author}

Tel.: +923318429767

E-mail: maryam38c@yahoo.com

\section{Keywords}

Canola meal

Exogenous enzyme

Organic acids

Productivity

Indian major carps

\begin{abstract}
Aquaculturists have been concentrating their efforts to design aquafeeds using agro by-products to reduce feed costs. However, the presence of a wide variety of antinutritional factors (ANFs) in plant materials is one of the major obstacles. For this purpose, a $2 \times 2$ factorial experiment was established to evaluate the suitability of canola meal with citric acid (CA) and phytase (PHY) supplementation for growth performance, nutrient digestibility and body composition of Labeo rohita fingerlings. Five isocaloric and isonitrogenous diets; D1 (control; without CA and PHY), D2 (CA 15 g/kg+PHY 1000 FTU/kg), D3 (CA 30 g/kg+PHY 1000 FTU/kg), D4 (CA 15 g/kg+PHY 2000 $\mathrm{FTU} / \mathrm{kg}$ ) and D5 (CA $30 \mathrm{~g} / \mathrm{kg}+\mathrm{PHY} 2000 \mathrm{FTU} / \mathrm{kg}$ ) were fed to fish (mean initial weight $7.61 \pm 0.31 \mathrm{~g}$ ) in triplicates for 90 -days. The growth performance was significantly increased while feed conversion ratio was decreased with D3 compared to control and other $\mathrm{CA}$ and $\mathrm{PHY}$ supplemented groups $(\mathrm{P}<0.05)$. Furthermore, higher digestibility $(\%)$ of nutrients (dry matter, crude protein and ash) and improved whole-body composition was also exhibited by fish fed with D3 $(P<0.05)$. Hence, the above results elucidate that supplementation of $30 \mathrm{~g} / \mathrm{kg}$ CA with $1000 \mathrm{FTU} / \mathrm{kg}$ PHY could be a useful approach for improved growth performance, nutrients digestibility and body composition of L. rohita.
\end{abstract}

\section{Introduction}

Sustainable aquaculture necessitates the development of nutritionally balanced aquafeeds comprising of essential fatty acids (EFAs), amino acids, vitamins and minerals (Zhou et al., 2004). Whereas to meet the increasing demands of the aquaculture industry, there is a need to explore cost-effective and readily available alternative feed ingredients (Lunger et al., 2007; Gatlin et al., 2007; Pham et al., 2008; NRC 2011; Bano and Afzal, 2017). In this regard, the inclusion of plant-based feed ingredients as a protein source is capturing the attention of researchers because of their easier availability and least cost (Hussian et al., 2011). Recently, employed fish feed ingredients among plant sources are soybean meal (SBM), rapeseed meal (RSM), canola meal (CM), cottonseed meal (CSM), sunflower meal (SFM), peanut meal (PNM), palm kernel meal (PKM), sesame meal (SM), coconut meal (CM), linseed meal (LSM) and other meals based on aquatic plants such as Azolla etc. (Mohammadi et al., 2016). By far, a number of studies have been undertaken to study the effect of these feed ingredients on growth performance and health parameters of various commercially valuable fish species, such as hybrid grouper (Epinephelus lanceolatus $\times$ E. fuscoguttatus), turbot (Scophthalmus 
maximus), Senegalese sole (Solea senegalensis), European catfish (Silurus glanis), marbled spinefoot (Siganus rivulatus), Nile tilapia (Oreochromis niloticus) and red sea bream (Pagrus major), etc. (Faudzi et al., 2017; Bai et al., 2017; Kumar et al., 2017; Monzer et al., 2017; Boonanuntanasarn et al., 2018).

Canola meal (CM) is a promising alternative to animal proteins due to its high protein content (38-40\%) and low contents of anti-nutritional factors (ANF) such as erucic acid (<2\%) and glucosinolates $(<30 \mu \mathrm{mol} / \mathrm{g})$ (McDonald et al., 1999; Naseem et al., 2006). One of the major obstacles has been the presence of a wide variety of noxious ANFs such as phytate, fibre, tannin, etc. concerning the inclusion of plant-based ingredients in aquafeeds (Baruah et al., 2004; Hussian et al., 2011). Phytate or phytic acid (Myo-inositol 1, 2, 3, 4, 5, 6hexaphosphate) is the main phosphorous storage component with a percentage of about $80 \%$ phosphorous in plants. It tends to build insoluble complexes with minerals, protein, carbohydrates, lipids and vitamins in the guts of fish, thereby making them unavailable to the fish (Papatryphon et al., 1999; Helland et al., 2006).

In this context, the provision of exogenous enzymes in aquafeeds has been successfully employed. For instance, phytase (PHY) hydrolyse phytatecomplexes hence, making phosphorus more available to fish (Baruah et al., 2007a). The PHY shows its optimum activity at two pH levels of 2.5 and 5.0-5.5 (Simons et al., 1990). Furthermore, it is not equally active in the entire digestive tract and the highest phytate hydrolysis by phytase is observed in the stomach (Yi et al., 1996). It has also been reported that dietary intake of PHY enhanced the growth performance of channel catfish, Ictalurus punctatus (Jackson et al., 1996; Li and Robinson, 1997), rainbow trout, Oncorhynchus mykiss (Roehustscord and Pfeffer 1995; Vielma et al., 1998), Korean rockfish, Sebastes schlegelii (Yoo et al., 2005) and rohu Labeo rohita (Hussian et al., 2011; Bano and Afzal, 2017).

Additionally, agastric fishes such as carps lack an acid secreting-stomach; therefore, most of the nutrients and minerals remain unavailable to fish and excreted to the environment (Cao et al., 2007). The previous studies reported that the inclusion of organic acids in feed formulations reduces intestinal $\mathrm{pH}$, leads to solubilization, absorption and utilization of nutrients in the intestine (Ravindran and Kornegay 1993; Khajepour et al., 2012; Liu et al., 2014). Among various organic acids dietary supplementation of citric acid (CA) in feeds showed desirable results; particularly in the case of poultry (Brenes et al., 2003; Kopecky et al., 2012) and pigs (Jongbloed et al., 2000; Gerritsen et al., 2010). In an in vitro study, dietary CA inclusion has resulted in hydrolyses of phytate complexes resulting in the release of phosphorous (Zyla et al., 1995). Moreover, dietary supplementation of CA and PHY resulted in improved growth performance, nutrient digestibility and mineral bioavailability in some important fish species such as
Indian carp (Baruah et al., 2007b), red sea bream (Hossian et al., 2007), common carp (Khajepour et al., 2012) and African catfish (Kemigabo et al., 2018).

Indian major carps (IMC) especially Labeo rohita commonly known as rohu, is largely consumed and cultured in the Asian region due to their good taste and high market attributes (Bano and Afzal, 2017). The present study has been designed to investigate the suitability of canola meal as a dietary protein source along with the combined effects of dietary CA and PHY supplementation on growth performance, nutrient digestibility and body composition of L. rohita.

\section{Material and Methods}

\section{Fish Husbandry}

All the experimental and analytical works were conducted according to the guidelines of the ethical committee of the University of Agriculture, Faisalabad (UAF), Pakistan. Labeo rohita fingerlings were transported from Government Fish Seed Hatchery to Fish Nutrition Laboratory Department of Zoology, UAF Pakistan. Fish were given a prophylactic dip (5 g $\mathrm{NaCl} / 1000 \mathrm{~mL}$ distilled water) for 5 minutes to avoid infections (Rowland and Ingram, 1991). During acclimatization, fish were fed once daily on the control diet for two weeks (Allan and Rowland, 1992). A total of 225 fingerlings (mean initial weight $7.62 \pm 0.16 \mathrm{~g}$ ) were randomly stocked in $\mathrm{V}$-shaped steel tanks $(60 \mathrm{~cm}$ height $\times 30 \mathrm{~cm}$ length $\times 30 \mathrm{~cm}$ width) at the density of 15 fish/tank (120 L water holding capacity).

\section{Experimental Diets and Design}

The raw feed ingredients were acquired from the local feed market, ground and sieved $(0.5 \mathrm{~mm})$. Chromic oxide was used as an inert marker at $1 \%$ to estimate nutrient digestibility coefficients (\%) of experimental diets. After weighing and mixing dry ingredients (Table $1)$, fish oil and distilled water (10-15\%) were added to acquire a suitable texture of dough. The floating pellets (3 $\mathrm{mm}$ ) were prepared by using an extruder (Jinan Saibainuo Machinery Co., Ltd., Model no. SYSLG30-IV Experimental Extruder) and excessive moisture of pellets was reduced by air drying. A $2 \times 2$ factorial experiment was established by supplementing two different doses (15 and $30 \mathrm{~g} / \mathrm{kg}$ ) of citric acid (SigmaAldrich $^{\circledR}$ W230618) and two different concentrations (1000 and 2000 FTU/kg) of microbial phytase (Phyzyme ${ }^{\circledR}$ XP 10000 FTU/g; Danisco Animal Nutrition, Fin-65101 Vaasa, Finland). Phytase (PHY) solution was prepared by adding $1000 \mathrm{~mL}$ of distilled water in $2 \mathrm{~g}$ of microbial phytase (powder form). The amount of phytase that generates $1 \mu \mathrm{mol}$ inorganic phosphorus/minute at $37^{\circ} \mathrm{C}$ and $\mathrm{pH} 5.5$ from the concentration $0.005 \mathrm{mmol} / \mathrm{L}$ of the substrate (sodium phytate) is defined as one unit phytase activity (Tayyab et al., 2017). Spraying method was used for supplementation of phytase and five 
experimental diets were prepared; control diet was set as CA $0 \mathrm{~g} / \mathrm{kg}+\mathrm{PHY} 0 \mathrm{FTU} / \mathrm{kg}$ named as D1 whereas, D2, D3, D4 and D5 supplemented with $15 \mathrm{~g} / \mathrm{kg} \mathrm{CA}+1000$ FTU/kg PHY, $30 \mathrm{~g} / \mathrm{kg} \mathrm{CA}+1000 \mathrm{FTU} / \mathrm{kg} \mathrm{PHY}, 15 \mathrm{~g} / \mathrm{kg}$ $\mathrm{CA}+2000 \mathrm{FTU} / \mathrm{kg} \mathrm{PHY}$ and $30 \mathrm{~g} / \mathrm{kg} \mathrm{CA}+2000 \mathrm{FTU} / \mathrm{kg} \mathrm{PHY}$, respectively (Table 1 ). Each experimental diet was given to three replicated tanks. All the diets were stored at 4 ${ }^{\circ} \mathrm{C}$ in airtight bags until feeding.

\section{Feeding Protocol and Faeces Collection}

Fish were hand-fed with their respective diet in two feeding sessions (morning and afternoon) at $3 \%$ body weight for 90 days. The uneaten diet particles were collected after 2 hours of feeding, dried and stored for feed consumption analysis. The faecal material was collected through a faecal collection tube from each tank separately after 02 hours of washing (Figure 1 and 2). Thin faecal strings (4-5g) were carefully collected, dried at $60{ }^{\circ} \mathrm{C}$ for 12 hours and stored separately to study the nutrient digestibility of experimental diets. Water quality variables such as temperature $(27.5 \pm 0.4$ $\left.{ }^{\circ} \mathrm{C}\right), \mathrm{pH}(7.8 \pm 0.4)$ and dissolved oxygen $(6.5 \pm 0.07 \mathrm{mg} / \mathrm{L})$ were monitored on daily basis through digital meters (HANNA, model HI 9147 and AMPROBE pH and DO meter). Natural photoperiod (12 hours light and 12 hours dark) was provided and aeration was maintained by a capillary system in all tanks.

\section{Calculations}

The mean initial weight $(\mathrm{g})$ of fish was recorded at the beginning of the feeding experiment and weight gain (g) was evaluated on a bi-weekly basis by weighing each tank individually. Initial length $(\mathrm{cm})$ was recorded by random selection of three $(n=3)$ fish from each tank and final length $(\mathrm{cm})$ was measured at the termination of the trial to calculated the condition factor. Growth parameters and feed conversion ratio (FCR) was determined by applying the following equations;

$$
\text { AWG }(\mathrm{g})=\text { Final weight }(\mathrm{g})-\text { Initial weight }(\mathrm{g})
$$

AWG: Absolute Weight Gain

$$
\text { WG } \%=\frac{\text { Final weight }(\mathrm{g})-\text { Initial weight }(\mathrm{g})}{\text { Initial weight }(\mathrm{g})} \times 100
$$

WG: Weight Gain

$$
\text { SGR }(\%)=\frac{\operatorname{Ln}(\text { Final weight })-\operatorname{Ln}(\text { Initial weight })}{\text { Initial weight }(\mathrm{g})} \times 100
$$

SGR: Specific Growth Rate

$$
\begin{gathered}
\text { Fulton condition factor }(\mathrm{K})=\frac{\text { Fish weight }(\mathrm{g})}{\text { Fish lenght }(\mathrm{cm})} \times 100 \\
\text { Feed conversion ratio }=\frac{\text { Dry feed intake }(\mathrm{g})}{\text { Wet weight gain }(\mathrm{g})}
\end{gathered}
$$

The apparent digestibility coefficient $(A D C)$ for the nutrients of CA and PHY supplemented canola mealbased diets was calculated by using formula given below;

Table 1. Ingredients and nutrient composition of experimental diets

\begin{tabular}{lccccc}
\hline Ingredients (g/kg) & D1 & D2 & D3 & D4 & D5 \\
\hline Fish meal & 120 & 120 & 120 & 120 & 120 \\
Canola meal & 540 & 540 & 540 & 540 & 540 \\
Wheat flour & 100 & 100 & 100 & 100 & 100 \\
Rice polish & 120 & 120 & 120 & 120 & 120 \\
Fish oil & 90 & 90 & 90 & 90 & 90 \\
Mineral mixture 1 & 20 & 20 & 20 & 20 & 20 \\
Vitamin premix & 20 & 20 & 20 & 20 & 20 \\
Ascorbic acid & 10 & 10 & 10 & 10 & 10 \\
Chromic oxide & 10 & 10 & 10 & 10 & 10 \\
\hline Analyzed nutrient composition of diets (on dry matter basis) & $9.5 \pm 0.2$ & $9.5 \pm 0.4$ & $9.7 \pm 0.0$ & $9.8 \pm 0.1$ \\
MC (g/kg) & $9.4 \pm 0.2$ & $320.4 \pm 0.4$ & $32.3 \pm 0.3$ & $321.8 \pm 0.5$ & $321.7 \pm 0.2$ \\
CP (g/kg) & $320.4 \pm 0.7$ & $111.8 \pm 0.5$ & $110.4 \pm 0.2$ & $110.4 \pm 0.8$ & $110.7 \pm 0.1$ \\
CL (g/kg) & $110.1 \pm 0.2$ & $90.6 \pm 0.5$ & $89.9 \pm 0.2$ & $88.9 \pm 0.3$ & $90.5 \pm 0.5$ \\
Ash (g/kg) & $88.8 \pm 0.3$ & $18.9 \pm 0.4$ & $19.5 \pm 0.2$ & $19.9 \pm 0.3$ & $19.6 \pm 0.5$ \\
GE (kcal/g) & $19.0 \pm 0.3$ & 15 & 30 & 15 & 30 \\
CA (g/kg) & 0 & 1000 & 1000 & 2000 & 2000 \\
PHY (FTU/kg) & 0 & & \\
\hline
\end{tabular}

${ }^{1}$ Each kg of mineral mixture contains; Ca (Calcium) $155 \mathrm{gm}, \mathrm{P}$ (Phosphorous) 135gm, Mg (Magnesium) 55gm, Na (Sodium) 45gm, Zn (Zinc) $3000 \mathrm{mg}$, Mn (Manganese) 2000 mg, Fe (Iron) 1000 mg, Cu (Copper) 600 mg, Co (Cobalt) 40 mg, I (lodine) 40mg, Se (Selenium) 3mg.

${ }^{2}$ Each kg of Vitamin premix contains; Vitamin A (Retinoic acid) $5.0 \mathrm{mg}$, Vitamin B1 (Thiamine) $0.5 \mathrm{mg}$, Vitamin B2 (Riboflavin) $3.0 \mathrm{mg}$, Vitamin B3 (Niacin) $5.0 \mathrm{mg}$, Vitamin B6 (Pyridoxine) $1.0 \mathrm{mg}$, Vitamin B7 (Biotin) $0.05 \mathrm{mg}$, Vitamin B9 (Folic acid) $0.18 \mathrm{mg}$, Vitamin B12 (Cobalamin) $0.002 \mathrm{mg}$, Vitamin C (Ascorbic acid) $5.0 \mathrm{mg}$, Vitamin D3 (Cholecalciferol) $0.002 \mathrm{mg}$, Cellulose $815.26 \mathrm{mg}$, Choline $100 \mathrm{mg}$. Abbreviations: $\mathrm{MC}=$ moisture content, $\mathrm{CP}=$ crude protein, $\mathrm{CL}=$ crude lipid, $\mathrm{GE}=$ gross energy, $\mathrm{CA}=$ citric acid, $\mathrm{PHY}=$ phytase. 

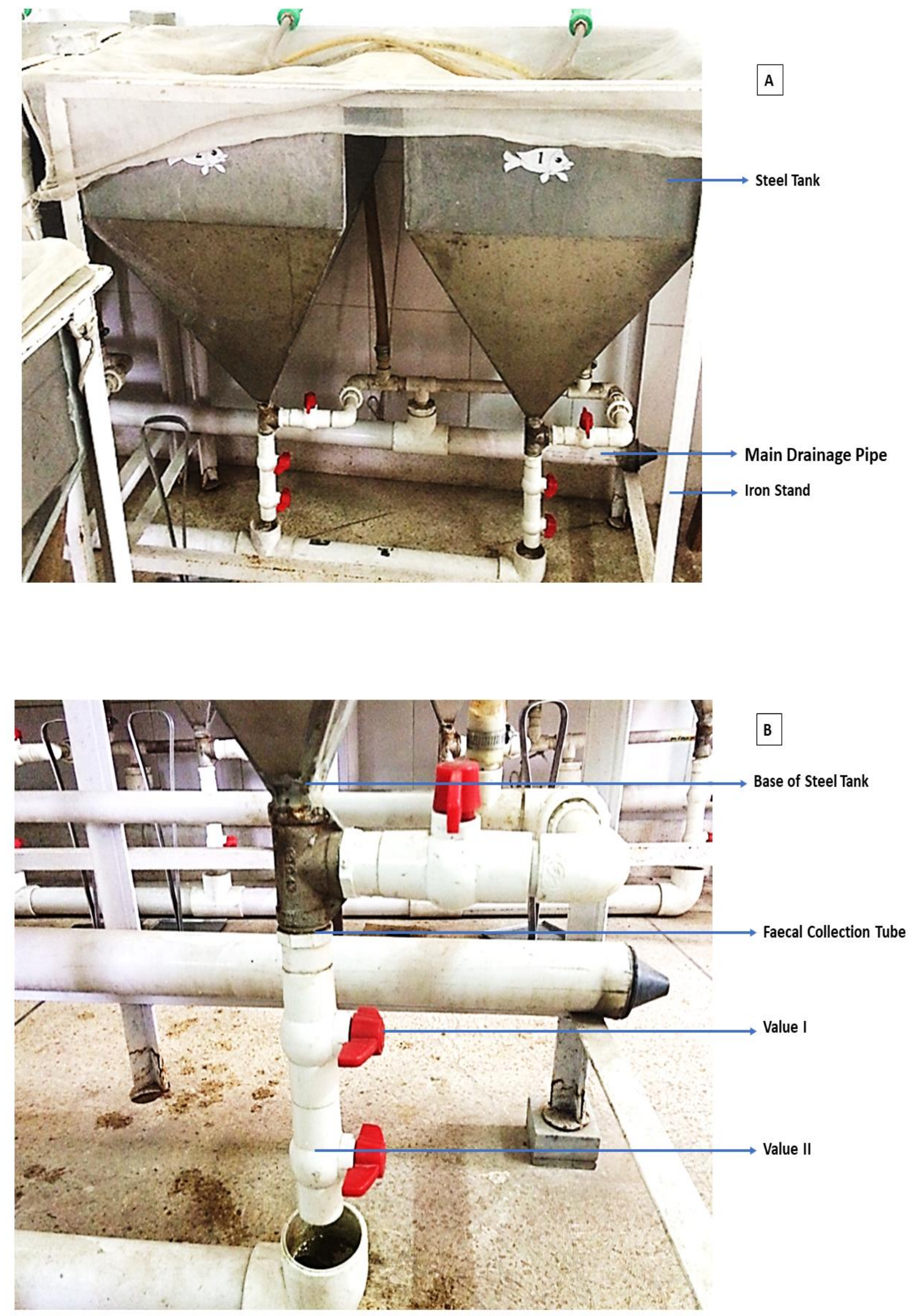

Figure 1. The outer view of (A) fish rearing steel tanks and (B) faeces collection tube 

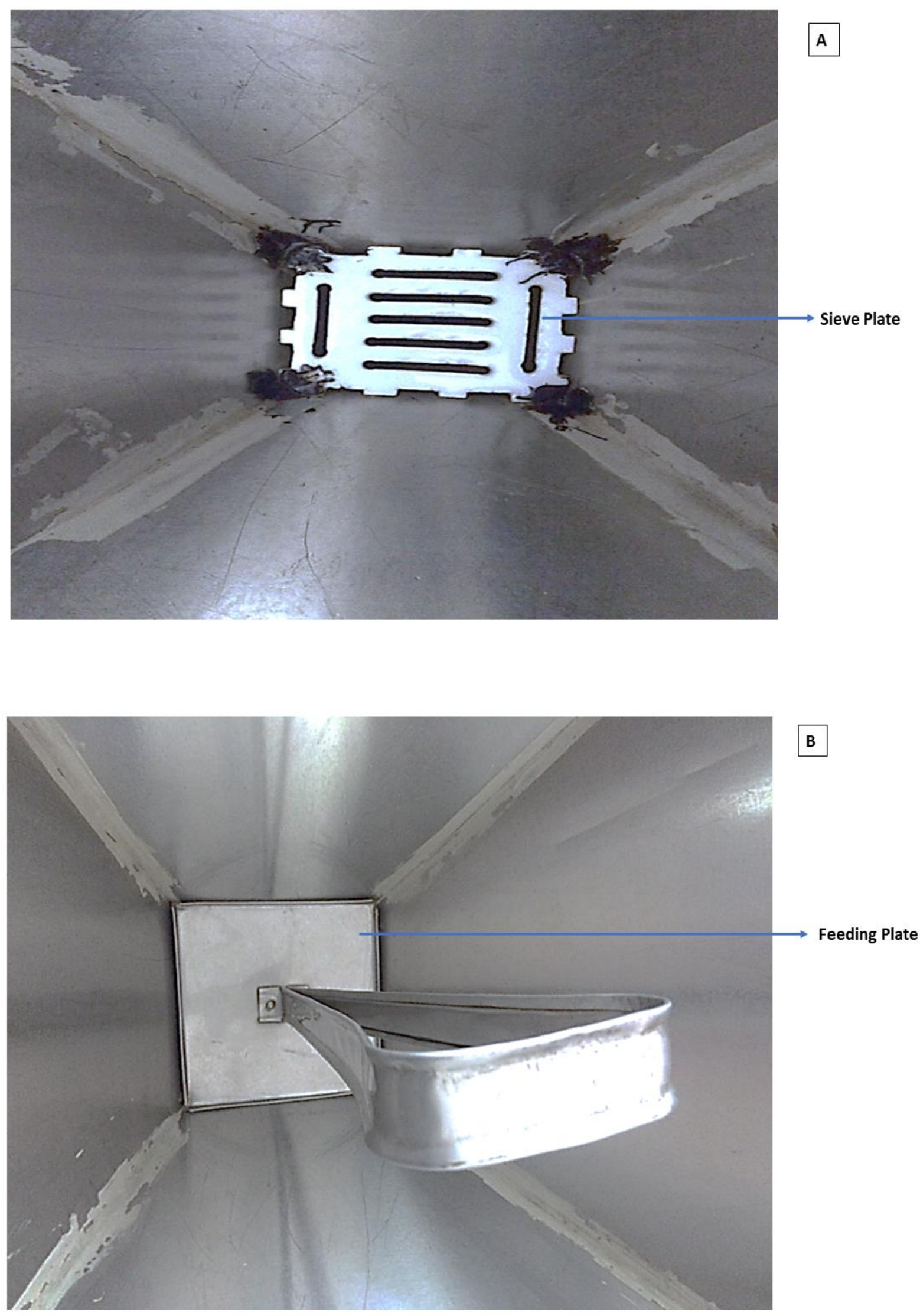

Figure 2. The inner view of fish rearing tanks with the (A) sieve plate and (B) feeding plate setup 
ADC of nutrient $(\%)=100-100 \frac{\% \text { of } \operatorname{cod} \times \% \text { of } \mathrm{nf}}{\% \text { of } \operatorname{cof} \times \% \text { of nd }}$

cod: chromic oxide in diet

nf: nutrient in feces

cof: chromic oxide in feces

nd: nutrient in diet

\section{Proximate Composition of Diets, Faeces and Experimental Fish}

The chemical composition of experimental diets, faeces and fish whole-body was analyzed (AOAC, 2006). At the termination of the growth experiment, five ( $n=5$; total 15 fish/diet) fish were randomly selected from each tank and oven dried (Memmert UN30). Dry matter content was calculated by constant drying at $105^{\circ} \mathrm{C}$ for 6 hours. Crude protein content was evaluated by nitrogen percentage $\left(\mathrm{N}_{2} \times 6.25\right)$ through the Kjeldhal method (Hanon K1100F micro- Kjeldhal auto analyzer). The ether extraction method was applied to determine crude lipid content by using the ether extraction method (Soxtec system HT2 1045) and an oxygen bomb calorimeter was used for gross energy calculation.

\section{Analysis of Chromic Oxide}

The chromic oxide contents in diets and faeces were estimated after oxidation with molybdate reagent using UV-VIS spectrophotometer (AE-S70-1U UK Co., Ltd.) at $440 \mathrm{~nm}$ (Divakaran et al., 2002).

\section{Statistical Analysis}

All data were collected as mean of three replicates $(n=3) \pm$ standard error of mean (SE). Two-way analysis of variance (ANOVA) was used to evaluate the effects of CA and PHY supplementation on growth performance, nutrient digestibility and whole-body composition of $L$. rohita fingerlings. Tukey's test was applied to determine the difference among the means of experimental groups and considered significant at $P<0.05$. SPSS software Version 22.0 IBM for Windows was used for all the statistical analysis of data.

\section{Results}

\section{Growth Performance}

The data of growth performance in terms of final weight (FW), absolute weight gain (AWG), weight gain percentage (WGP), specific growth rate (SGR) and Fulton's condition factor $(K)$ of $L$. rohita fingerlings in response to citric acid (CA) and phytase (PHY) supplementation are summarized in Table 2. After the feeding period of 90 -days, significant $(P<0.05)$ interaction was observed for growth performance and FCR. FW, AWG, WGP, SGR and $K$ was significantly $(P<0.05)$ higher however, $F C R$ was significantly $(P<0.05)$ lower in fish fed with D3 (30 g/kg CA+1000 FTU/kg PHY) compared to D1; control (0 g/kg CA+0 FTU/kg PHY) and other CA and PHY supplemented groups (Table 2 ).

\section{Apparent Nutrient Digestibility (\%)}

The supplementation of CA and PHY had a significant effect on apparent digestibility (\%) of nutrients i. e. dry matter (DM), crude protein (CP), crude lipids (CL), and gross energy (GE) for canola meal-based diets fed to $L$. rohita fingerlings (Table 3). The apparent digestibility (\%) of DM, CP, CL and GE was significantly

Table 2. Growth performance and survival (\%) of L. rohita fingerlings fed with canola meal-based citric acid and phytase supplemented diets

\begin{tabular}{|c|c|c|c|c|c|c|c|c|}
\hline Parameters & D1 & D2 & D3 & D4 & D5 & $\mathrm{CA}$ & $\mathrm{PYH}$ & $\mathrm{CA} \times \mathrm{PHY}$ \\
\hline IW (g) & $7.30 \pm 0.10$ & $7.78 \pm 0.11$ & $7.62 \pm 0.10$ & $7.67 \pm 0.11$ & $7.55 \pm 0.14$ & & & \\
\hline FW (g) & $12.38 \pm 0.31^{d}$ & $16.31 \pm 0.39^{c}$ & $23.49 \pm 0.72^{\mathrm{a}}$ & $15.02 \pm 0.19^{c}$ & $18.94 \pm 0.71^{b}$ & 0.000 & 0.000 & 0.000 \\
\hline AWG (g) & $5.08 \pm 0.38^{d}$ & $8.52 \pm 0.40^{c}$ & $15.87 \pm 0.82^{\mathrm{a}}$ & $7.35 \pm 0.08^{c}$ & $11.39 \pm 0.84^{b}$ & 0.000 & 0.000 & 0.000 \\
\hline WG (\%) & $69.68 \pm 6.03^{c}$ & $109.59 \pm 5.83^{b c}$ & $208.60 \pm 13.87^{a}$ & $95.83 \pm 0.28^{c}$ & $151.22 \pm 13.79^{b}$ & 0.000 & 0.000 & 0.000 \\
\hline SGR $\left(\%\right.$ day $\left.^{-1}\right)$ & $1.79 \pm 0.08^{d}$ & $2.37 \pm 0.05^{c}$ & $3.06 \pm 0.05^{a}$ & $2.21 \pm 0.01^{c}$ & $2.69 \pm 0.08^{\mathrm{b}}$ & 0.000 & 0.000 & 0.000 \\
\hline K & $1.21 \pm 0.03^{d}$ & $1.60 \pm 0.03^{c}$ & $2.30 \pm 0.07^{a}$ & $1.47 \pm 0.01^{c}$ & $1.86 \pm 0.07^{b}$ & 0.000 & 0.000 & 0.000 \\
\hline FCR & $2.40 \pm 0.23^{a}$ & $1.60 \pm 0.03^{b c}$ & $1.12 \pm 0.05^{d}$ & $1.74 \pm 0.16^{b}$ & $1.33 \pm 0.02^{\mathrm{cd}}$ & 0.000 & 0.008 & 0.000 \\
\hline
\end{tabular}

The data are presented as mean $(n=3) \pm$ standard error of mean (SE). Means within the same row having different superscript are significantly different $(P<0.05)$. Abbreviations: $I W=$ initial weight, $F W=$ final weight, $A W G=$ absolute weight gain, $W G(\%)=$ weight gain percentage, $S G R=s p e c i f i c$ growth rate, $\mathrm{K}=$ Fulton condition factor, $\mathrm{FCR}=$ feed conversion ratio.

Table 3. The nutrient digestibility coefficient (\%) of citric acid and phytase supplemented canola meal-based diets fed to $L$. rohita fingerlings

\begin{tabular}{|c|c|c|c|c|c|c|c|c|}
\hline Digestibility (\%) & D1 & D2 & D3 & D4 & D5 & $\mathrm{CA}$ & PYH & $\mathrm{CA} \times \mathrm{PHY}$ \\
\hline DM & $52.64 \pm 0.26^{d}$ & $53.16 \pm 0.43^{c}$ & $65.24 \pm 0.86^{a}$ & $56.29 \pm 0.35^{c}$ & $60.29 \pm 0.035^{b}$ & 0.000 & 0.007 & 0.000 \\
\hline $\mathrm{CP}$ & $64.74 \pm 0.55^{d}$ & $67.64 \pm 0.93^{c}$ & $76.86 \pm 0.58^{a}$ & $65.48 \pm 0.47^{c d}$ & $71.44 \pm 0.28^{b}$ & 0.001 & 0.000 & 0.000 \\
\hline $\mathrm{CL}$ & $61.83 \pm 0.37^{d}$ & $64.58 \pm 0.30^{c}$ & $72.63 \pm 0.31^{a}$ & $64.34 \pm 0.24^{c}$ & $69.21 \pm 0.17^{b}$ & 0.000 & 0.000 & 0.000 \\
\hline GE & $52.35 \pm 1.11^{c}$ & $55.19 \pm 0.42^{c}$ & $67.64 \pm 0.57^{a}$ & $58.61 \pm 0.42^{b}$ & $60.74 \pm 0.20^{b}$ & 0.000 & 0.000 & 0.000 \\
\hline
\end{tabular}

The data are presented as mean $(n=3) \pm$ standard error of mean (SE). Means within the same row having different superscript are significantly different $(\mathrm{P}<0.05)$. Abbreviations: $\mathrm{DM}=$ dry matter, $\mathrm{CP}=$ crude protein, $\mathrm{CL}=$ crude lipids, $\mathrm{GE}=$ gross energy. 
$(P<0.05)$ increased in group fed with D3 $(30 \mathrm{~g} / \mathrm{kg}$ $\mathrm{CA}+1000 \mathrm{FTU} / \mathrm{kg} \mathrm{PHY}$ ), followed by group fed D5 (30 $\mathrm{g} / \mathrm{kg} \mathrm{CA}+2000 \mathrm{FTU} / \mathrm{kg} \mathrm{PHY})$. Whereas, significantly $(P<0.05)$ decreased nutrient i. e. $D M, C P, C L$ and $G E$ digestibility (\%) was exhibited by control diet $(0 \mathrm{~g} / \mathrm{kg}$ $\mathrm{CA}+0 \mathrm{FTU} / \mathrm{kg} \mathrm{PHY}$ ) compared to other experimental groups (Table 3 ).

\section{Proximate Composition of Whole-Body}

The significant interaction of CA and PHY supplementation was observed for whole-body composition of $L$. rohita fingerlings, after the feeding period of 90-days. The significantly $(P<0.05)$ improved whole-body dry matter, crude protein and ash content was displayed by the group fed with D3 (30 g/kg CA+1000 FTU/kg PHY), followed by D5 (30 g/kg CA+1000 $\mathrm{FTU} / \mathrm{kg} \mathrm{PHY}$ ) and significantly lowest DM, CP and ash content was observed in fish fed D1 $(0 \mathrm{~g} / \mathrm{kg} \mathrm{CA}+0 \mathrm{FTU} / \mathrm{kg}$ PHY) (Figure $3 \mathrm{~A}, \mathrm{~B}, \mathrm{D})$. Inversely, significantly $(\mathrm{P}<0.05)$ lowest whole-body crude lipid content was exhibited by groups fed D3 (30 g/kg CA+1000 FTU/kg PHY) however, highest crude lipid content was observed in fish fed control diet ( $0 \mathrm{~g} / \mathrm{kg} \mathrm{CA}+0 \mathrm{FTU} / \mathrm{kg}$ PHY) (Figure 3, C).

\section{Discussion}

In the present study, positive interaction was observed between CA and PHY which improved growth performance of $L$. rohita. Similar findings were reported by Khajepour et al. (2012) with common carp, Cyprinus carpio and Khajepour and Hosseini (2012) in beluga, Huso huso. The dietary acidification stimulates the activity of digestive enzymes in fish gut and optimizes the digestion and utilization of nutrients and minerals (Hussain et al., 2011a). Additionally, acidification provides favorable environmental conditions for phytase to diminish the level of phytate in digesta, thus basically inhibits the formation of phytate-protein-mineral complexes (Liebert and Portz, 2005). Citric acid has been evaluated to make stronger dephosphorylation of phytate in vitro (Sakata et al., 1995). Whereas, this increased growth with CA at 30 $\mathrm{g} / \mathrm{kg}$ and PHY at $1000 \mathrm{FTU} / \mathrm{kg}$ clearly indicates that dietary supplementation of CA and PHY showed dose dependent response for growth performance in L. rohita in current study. Contrary, no significant interaction of PHY and CA supplementation on growth performance was reported by Zhu et al. (2015) which can be due to the suitability of stomach $\mathrm{pH}$ of yellow catfish. This contradictory interaction of $\mathrm{PHY}$ and $\mathrm{CA}$ on growth performance may be mainly due to different experimental fish species, which may have a stomach or not (Shah et al., 2015a).

Furthermore, significantly reduced FCR was measured with CA at $30 \mathrm{~g} / \mathrm{kg}$ and PHY at $1000 \mathrm{FTU} / \mathrm{kg}$ supplementation compared to control and other CA and PHY supplemented groups in present study which is in agreement with the previous results with Indian major carps, red sea bream, rainbow trout and yellowtail (Baruah et al., 2007a; Hussian et al., 2011a; Hussian et al., 2011b; Sarker et al., 2012). Evidences suggested that dietary intake of CA and PHY results in the availability of various nutrients such as, phosphorous and calcium which makes the diet nutrient efficient. Additionally, CA and PHY improves the epithelial proliferation and adsorption of nutrients by enhancing the pancreatic secretion in gastrointestinal tract (De Wet, 2005; Baruah et al., 2007b).

In the present study, improved digestibility of dry matter (DM) was observed with dietary supplementation of CA and PHY in L. rohita compared to control. However, highest digesitibility of DM was observed with $30 \mathrm{~g} / \mathrm{kg} \mathrm{CA}$ and $1000 \mathrm{FTU} / \mathrm{kg}$ PHY which is supported by the findings of Phromkunthong et al. (2010) and Sari et al. (2012) in C. carpio and hens, respectively. CA has antimicrobial activities thus, reduces the pathogenic load in fish intestineconsequently enhancing the absorption and utilization of nutrients which improved the digestibility of DM (Shah et al., 2015a). Additionally, CA improves gut health and facilitates digestion by lowering intestinal $\mathrm{pH}$ (Baruah et al., 2005). Moreover, phytase breakdowns the phytate-phosphorous complexes and convert tricalcium phosphate into the available form of phosphorus and other nutrients (Sarker et al., 2005; Liebert and Portz, 2005).

Similarly, increased digestibility of crude protein (CP) was observed due to the positive interaction of CA $(30 \mathrm{~g} / \mathrm{kg})$ and PHY $(1000 \mathrm{FTU} / \mathrm{kg})$ in L. rohita which is similar to the reports of Bano and Afzal (2017) in $L$. rohita and Phromkunthong et al. (2010) in Cyprinus carpio. Some previous studies have suggested improved digestibility of $\mathrm{CP}$ with the inclusion of organic acids and exogenous enzymes (Baruah et al., 2007b; Khajepour and Hosseini, 2012). CA disrupts the cell wall of plant materials and stimulates the proteolytic enzymes activity such as pepsin and trypsin resulting in improved protein digestibility (Bano and Afzal, 2017; Hussain et al., 2017). Also, phytate present in plant material may chelate with amino acids in the stomach of fish thus, reduces the availability of amino acid. Whereas, the dietary supplementation of PHY improves the liberation of nutrients (especially amino acids) from plant materials in fish intestine (Usmani and Jafri, 2002). Though, the digestibility of nutrients is also (CA and PHY) dose dependent and species-pecific function (Cao et al., 2007).

The digestibility of crude lipids (CL) was significantly increased with $\mathrm{CA}$ at $30 \mathrm{~g} / \mathrm{kg}$ and PHY at $1000 \mathrm{FTU} / \mathrm{kg}$ compared to control and other CA and PHY supplemented groups in the present work which is in line with the findings of Ashraf and Goda (2007) and Portz and Liebert (2005) in Nile tilapia (Oreochromis niloticus). It has been reported that CA supplementation lowers the rate of gastric emptying by modifying gastric $\mathrm{pH}$, hence improves the $\mathrm{CL}$ digestibility (Shah et al., 2015a). Phytase in the presence of CA improves the 

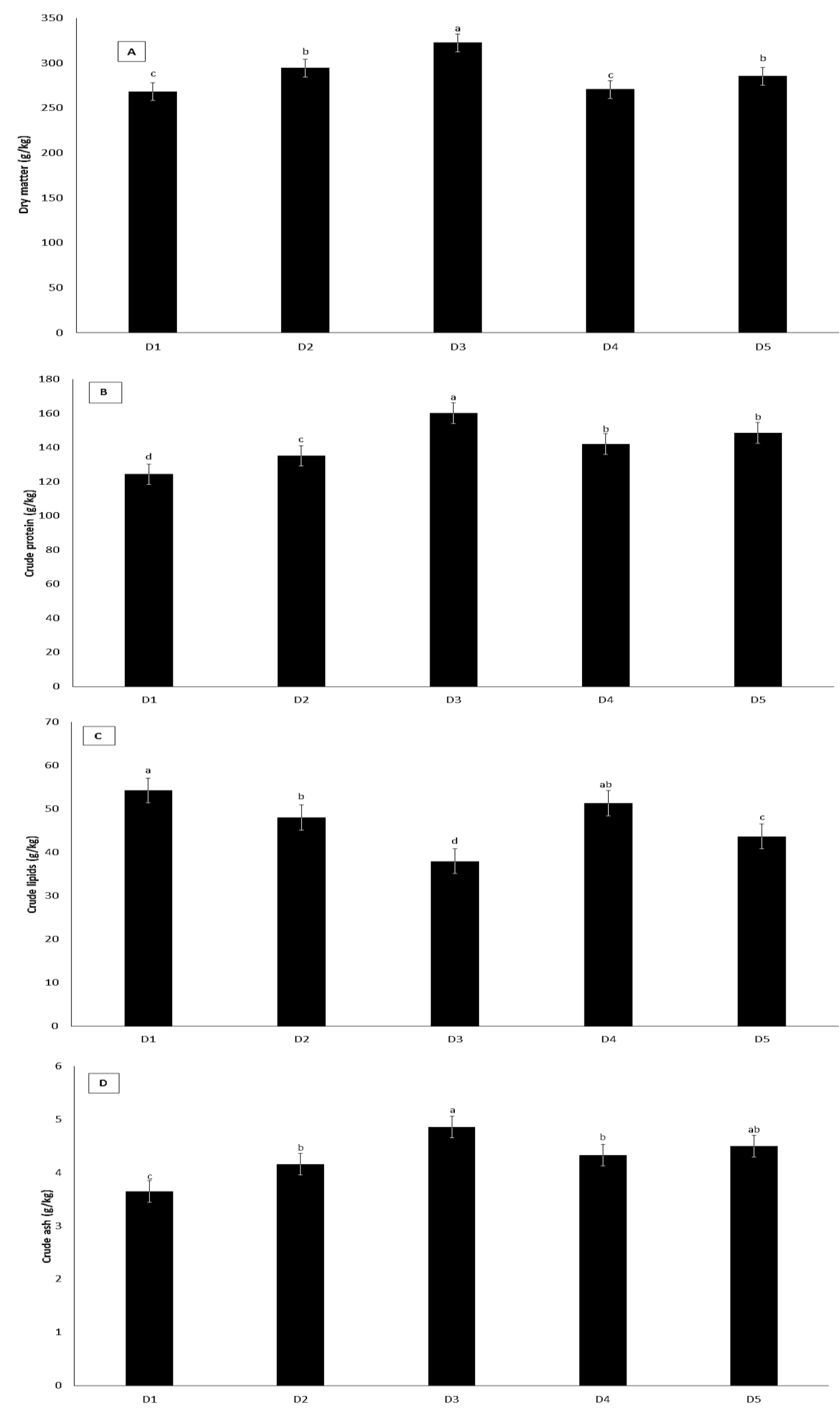

Figure 3. The whole-body dry matter, crude protein, crude lipids and crude ash $(\mathrm{g} / \mathrm{kg})$ content of $L$. rohita fingerlings fed with citric acid and phytase supplemented canola meal-based diets. Graph bars showing mean value of three replicates $(n=3)$. The dietary treatments having different superscripts are significantly different at $P<0.05$. 
availability of phosphorous thus, it inhibits the $\beta$ oxidation of fatty acids resulting from the deficiency of phosphorous (Atapattu and Nelligaswatta, 2005; Shah et al., 2015b; Schafer et al., 1995).

Similarly, digestibility of gross energy (GE) was also significantly highest due to the positive interaction of CA at $30 \mathrm{~g} / \mathrm{kg}$ and PHY at $1000 \mathrm{FTU} / \mathrm{kg}$ supplementation which is comparable to some previous reports (Boiling et al., 2000; Nourmohammadi et al., 2012; Hussain et al., 2015). CA regulates different vital energy yielding intermediary metabolic processes like ATP formation in TCA cycle, thus provides the energy to the cell (Diebold and Eidelsburger, 2006). Furthermore, metallic soap is formed by the accretion of lipids, calcium and phytate which diminishes the apparent digestibility of energy. While, hydrolyzation of phytate-nutrient complex by phytase, may not discharge the nutrients into faeces and become available to the fish thus, enhanced the digestibility of energy (Bano and Afzal 2017; Hussain et al., 2015; Gatlin III, 2000). Some studies suggested that 5\% CA and $750 \mathrm{FTU} / \mathrm{kg}$ was sufficient to improve nutrient digestibility (Hussain et al., 2015). The plausible explanation of this contradiction in doses might be differences in feed manufacturing technique, plant metarial, enzyme sources and concentrations and difference in fish species (Mroz et al., 2000; Sarker et al., 2005; Cao et al., 2007).

The dietary supplementation of CA and PHY showed positive influence on the whole-body proximate composition of $L$. rohita, in present study. The dry matter (DM), crude protein (CP) and ash content was significantly higher however, crude lipid (CL) content was lower with $30 \mathrm{~g} / \mathrm{kg} \mathrm{CA}$ and $1000 \mathrm{FTU} / \mathrm{kg} \mathrm{PHY}$ compared to control and other CA and PHY supplemented groups. This result is in line with the findings of Khajepour and Hosseini (2012) in C. carpio. CA along with the dietary supplementation of PHY is considered as a significant factor for improved uptake of dietary nutrietns and minerals (calcium, phophorous and zinc) for aquatic as well as for terrestrial cultured animals (Bano and Afzal, 2017). Thus, improved proximate composition of $L$. rohita in the present study might be result of synergistic effect of CA and PHY supplementation on fish body. Whereas, Hossain et al. (2007) found no significant effect of CA supplementation on whole-body composition of red sea bream which might be the result of difference in fish species used for study.

In conclusion, interaction of CA and PHY enhances the nutrient digestibility which leads to improved growth performance and body composition; additionally, this effect of CA was dose dependent. Hence, canola meal might be a suitable protein source for improved growth performance, nutrients digestibility and body composition of $L$. rohita fingerlings along with the dietary supplementation of CA at $30 \mathrm{~g} / \mathrm{kg}$ and $\mathrm{PHY}$ at $1000 \mathrm{FTU} / \mathrm{kg}$.

\section{Data Availability Statement}

The data that support the findings of the present study is already provided within the manuscript.

\section{Ethical Statement}

The experimental protocol was approved by the Ethics Committee of University of Agriculture, Faisalabad (UAF) Pakistan.

\section{Funding Information}

Not applicable.

\section{Author Contribution}

Maryam Iqbal: Conceptualization, Methodology, Data Curation, Formal Analysis, Writing -review and editing; Muhammad Afzal: Supervision, Investigation, Visualization, review and editing; Atif Yaqub: Writing review and editing; Khalid Mahmood Anjum: Resources and Analysis; Komal Tayyab: Experimentation and Methodology.

\section{Conflict of Interest}

The authors declare that they have no known competing financial or non-financial, professional, or personal conflict of interest.

\section{Acknowledgements}

The authors are thankful to the Government Fish Seed Hatchery, Faisalabad for fish seed and Hi-Tech Laboratory, University of Agriculture, Faisalabad Pakistan for providing the analytical facility.

\section{References}

Allan, G.L. \& Rowland, S.J. (1992). Development of an experimental diet for silver perch (Bidyanus bidyanus). Journal of Australasian Aquaculture, 6, 39-40.

AOAC, (2006). Association of Analytical Chemist. Official Methods of Analysis of AOAC International. Horwitz, W. \& Latimer, G.W. $18^{\text {th }}$ Edition, Gaithersburg, Maryland.

Ashraf, M.A.S. Goda. (2007). Effect of dietary soybean meal and phytase levels on growth, feed utilization and phosphorus discharge for Nile tilapia Oreochromis niloticus (L). Journal of Fisheries and Aquatic Science, 2, 248-263. https://doi.org/10.3923/jfas.2007.248.263.

Atapattu, N.S.B.M. \& Nelligaswatta, C.J. (2005). Effects of citric acid on the performance and the utilization of phosphorous and crude protein in broiler chickens fed on rice by -products based diets. International Journal of Poultry \& Science, 4, 990-993.

Bai, N., Gu, M., Xu, X., Xu, B. \& Krogdahl, A. (2017). Protective effects of mannan oligosaccharides on turbot Scophthalmus maximus suffering from soy enteropathy. 
Aquaculture,

https://doi.org/10.1016/j.aquaculture.2017.04.005.

Bano, N. \& Afzal, M. (2017). Synchronized effect of citric acid and phytase supplementation on growth performance and nutrient digestibility of Labeo rohita. Aquaculture Nutrition, 00, 1-7. https://doi.org/10.1111/anu.12607.

Baruah, K., Pal A.K., Sahu, N.P., Jain, K.K., Mukherjee, S.C. \& Debnath, D. (2005). Dietary protein level, microbial phytase, citric acid and their interactions on digestibility of Labeo rohita juveniles. Journal of Aquaculture Research, 36, 803-812.

https://doi.org/10.1111/j.1365-2109.2005.01290.x.

Baruah, K., Pal, A.K., Sahu, N.P., Debnath, D. \& Yengkokpam, S. (2007a). Interactions of dietary microbial phytase, citric acid and crude protein level on mineral utilization by rohu, Labeo rohita (Hamilton), juveniles. Journal of World Aquaculture Society, 38, 238-249. https://doi.org/10.1111/j.1749-7345.2007.00092.x.

Baruah, K., Sahu, N.P., Pal A. K. \& Debnath, D. (2004). Dietary Phytase: An ideal approach for a cost effective and low polluting aqua feed. NAGA, World Fish Center Quarterly Volume, 27,15-19. https://hdl.handle.net.20.500.12348/2061.

Baruah, K., Sahu, N.P., Pal, A.K., Jain, K.K., Debnath, D. \& Mukherjee, S.C. (2007b). Dietary microbial phytase and citric acid synergistically enhances nutrient digestibility and growth performance of Labeo rohita juveniles at sub-optimal protein level. Journal of Aquaculture Research, 38, 109-120. http://hdl.handle.net/1854/LU443827

Boling, S.D., Webel, D.M., Mavromichalis, I., Parsons, C.M. \& Baker, D.H. (2000). The effects of citric acid on phytate phosphorus utilization in young chicks and pigs. Journal of Animal Science, 78, 682-689. https://doi.org/10.2527/2000.783682x.

Boonanuntanasarn, S., Suksan, K., Kirana, Y., Elisabeth, P., Christine, B., Lucie, M. \& Stephane P. (2018). Molecular responses of Nile tilapia (Oreochromis niloticus) to different levels of dietary carbohydrates. Aquaculture, 482, 117-123.

https://doi.org/10.1016/j.aquaculture.2018.07.011.

Brenes, A., Viveros, A., Arija, I., Centeno, C., Pizarro, M. \& Bravo, C. (2003). The effect of citric acid and microbial phytase on mineral utilization in broiler chicks. Animal Feed Science and Technology, 110, 201-219. https://doi.org/10.1016/S0377-8401(03)00207-4.

Cao, L., Wang, W., Yang, C., Yang, Y., Diana, J., Yakupitiyage, A., Luoa, Z. \& Li, D. (2007). Application of microbial phytase in fish feed. Enzyme and Microbial Technology, 40, 497507.http://www.sciencedirect.com/science/acticle/pii/ S0141022907000245.

De Wet, L. (2005). Organic acids as performance enhancers. Aquaculture Feeds Formulation Beyond, 2, 12-14. https://doi.org/10.1079/PAVSNNR20083044.

Diebold, G. \& Eidelsburger U. (2006). Acidification of diets as an alternative to antibiotic growth promoters. In: Barug D, de Jong J, Kies A.K., Verstegen M.W.S., editors. Antimicrobial Growth Promoters. 1st ed. Wageningen Academic Publishers; Wageningen, The Netherlands: 311-327.

Divakaran, S., G. O. Leonard \& P. F. Ian. (2002). Note on the methods for determinate chromic oxide in shrimp feeds. Journal of Agriculture Food and Chemistry, 50: 464-467. https://doi.org/10.1021/jf011112s.
Faudzi, N.M., Yong, A.S.K., Shapawi, R, Senoo, S., Biswas, A. \& Takii, K. (2017). Soy protein concentrate as an alternative in replacement of fish meal in the feeds of hybrid grouper, brown-marbled grouper (Epinephelus fuscoguttatus) 3 giant grouper (E. lanceolatus) juvenile. Aquaculture Research, 00, 1-11. https://doi.org/10.1111/are.13474.

Gatlin, III D.M., Barrows, F.T., Brown, P., Dabrowski, K., Gaylord, T.G., Hardy, R.W., Herman, E., Hu, G. Krogdahl, A., Nelson, R., Overturf, K. Rust, M., Sealey, W. Skonberg, D., Souza, E. J. Stone, D., Wilson, R. \& Wurtel, E. (2007). Expanding the utilization of sustainable plant products in aqua feeds: a review. Journal of Aquaculture Research, 38, 551-579. https://doi.org/10.1111/j.1365 2109.2007.01704.x.

Gerritsen, R., Van Dijk, A.J., Rethy, K. \& Bikker, P. (2010). The effect of blends of organic acids on apparent faecal digestibility in piglets. Livestock Science, 134, 246-248. https://doi.org/10.1016/j.livsci.2010.06.154.

Helland, S., Denstadli, V., Witten, P. E., Hjelde, K., Strobakken, T., Skrede, A., Asgard, T. \& Baeverfjord, G. (2006). Hyper dense vertebrae and mineral content in Atlantic salmon (Salmo salar $\mathrm{L}$ ) fed diets with graded levels of phytic acid. Aquaculture, 261, 603-614. https://doi.org/10.1111/j.1749-7345.2010.00416.x.

Hossain, M.A., Pandey, A. \& Satoh, S. (2007). Effects of organic acids on growth and phosphorus utilization in red sea bream Pagrus major. Fisheries Science, 73, 1309-17. doi:10.1111/j.1444-2906.2007.01469.x.

Hussain, S.M., Afzal, M., Rana, S. A., Javid, A. \& Iqbal, M. (2011b). Effect of phytase supplementation on growth performance and nutrient digestibility of Labeo rohita fingerlings fed on corn gluten meal-based diets. International Journal of Agriculture and Biology, 13, 916922.

Hussain, S.M., Afzal, M., Rana, S.A., Javid A., \& Hussain, M. (2011a). Impact of phytase supplementation on nutrient digestibility for Labeo rohita fingerlings fed on sunflower meal-based diets. Pakistan Journal of Life and Social Sciences, 9, 85-90.

Hussain, S.M., Ahmad, N., Jabeen, F., Javid, A., Aslam, N., Husain, M. \& Shahzad, M.M. (2015). Effects of citric acid and phytase supplementation on nutrient digestibility and growth performance of Cirrhinus mrigala fingerlings fed on corn gluten (30\%) meal-based diets. International Journal of Biosciences, 6, 82-91.

Hussian, S.M., Hameed, T., Afzal, M., Javid, A., Aslam, N., Shah, S.Z.H., Hussain, M., Arslan, M.Z.H. \& Shahzad, M.M. (2017). Growth performance and nutrient digestibility of Cirrihinus mrigala fingerlings fed phytase supplemented sunflower meal-based diet. Pakistan Journal of Zoology, 49, 1713-1724.

https://https://doi.org/10.17582/journal.pjz/2017.49.1 713.1724

Jackson, L.S., Li, M. H. \& Robinson, E. H. (1996). Use of microbial phytase in channel cat fish, Ictalurus punctatus diets to improve utilization of phytate phosphorus. Journal of World Aquaculture Society, 27, 309-313. https://https://doi.org/10.1111/j.1749-7345. 1996.tb00613.x.

Jongbloed, A.W., Mroz, Z., Weij-Jongbloed, R., \& Kemme, P.A. (2000). The effects of microbial phytase, organic acids and their interaction in diets for growing pigs. Livestock Production Science, 67, 113-122. https://https://doi.org/10.1016/S0301-6226(00)00179-2 
Kemigabo, C., Abdel-Tawwab, M., Lazaro, J.W., Sikawa, D., Masembe, C. \& Kang'Ombe, J. (2018). Combined effect of dietary protein and phytase levels on growth performance, feed utilization, and nutrients digestibility of African catfish, Clarias gariepinus (B.) reared in earthen ponds. Journal of Applied Aquaculture. https://doi.org/10.1080/10454438.2018.1439425.

Khajepour, F. \& Hosseini, S.A. (2012). Calcium and phosphorus status in juvenile beluga (Huso huso) fed citric acidsupplemented diets. Aquaculture Research, 43, 407-411. https://doi.org/10.1111/j.1365-2109.2011. 02843.x.

Khajepour, F., Hosseini, S. A. \& Imanpour, M.R. (2012). Dietary crude protein, citric acid and microbial phytase and their interacts to influence growth performance, muscle proximate composition and hematocrite of common carp, Cyprinus carpio L, juveniles. World Journal of Zoology, 7, 118-122.

https://doi.org/10.5829/idosi.wjz.2012.7.2.56344.

Kopecky J., Hrncar, C. \& Weis, J. (2012). Effect of organic acids supplement on performance of broiler chickens. Animal Science and Biotechnologies, 45, 51-54.

Kumar, S., Zs, J.S., Nagy, Z., Fazekas, G., Havasi, M., Sinha, A.K., Boeck, G.D. \& Gal, D. (2017). Potential of processed animal protein versus soybean meal to replace fish meal in practical diets for European catfish (Silurus glanis): growth response and liver gene expression. Aquaculture Nutrition, 00, 1-7. https://https://doi.org/10.1111/anu.12487.

Li, M.H. \& Robinson, E.H. (1997). Microbial phytase can replace inorganic phosphorus supplements in channel catfish Ictalurus punctatus diets. Journal of World Aquaculture Society, 28, 402-406. https://doi.org/10.1111/j.17497345.1997.tb00287.x.

Liebert, F., \& Portz, L. (2005). Nutrient utilization of Nile tilapia (Oreochromis niloticus) fed plant based low phosphorous diets supplemented with graded levels of different sources of microbial phytase. Aquaculture, 248, 111-119.

https://doi.org/10.1016/j.aquaculture.2005.04.009.

Liu, S.T., Hou, W.X., Cheng, S.Y., Shi, B.M. \& Shan, A.S. (2014). Effects of dietary citric acid on performance, digestibility of calcium and phosphorus, milk composition and immunoglobulin in sows during late gestation and lactation. Animal Feed Science and Technology, https://doi.org/10.1016/j.anifeedsci.2014.01.017.

Lunger, A.N., McLean, E. \& Craig, S.R. (2007). The effects of organic protein supplementation upon growth feed conversion and texture quality parameters in juvenile cobia (Rachycentron canadum). Aquaculture, 264, 342352.

https://doi.org/10.1016/j.aquaculture.2006.12.012.

McDonald, P., Edwards, R.A., Greenhalgh J.F.D. \& Morgan, C.A. (1999). Animal Nutrition, 5th Edition, p. 546-564.

Mohammadi, M., Sarsangi, H., Mashaei, N., Rajabipour, F., Bitarat, A. \& Hafeziyeh, M. (2016). Canola Substitution in Nile Tilapia Oreochromis niloticus Diets. Journal of Cell Science \& Therapy, 7, 256.

https://doi.org/10.4172/2157-7013.1000256.

Monzer, S., Nasser, N., Babikian, J. \& Saoud, I.P. (2017). Substitution of fish meal by soybean meal in diets for juvenile marbled spinefoot, Siganus rivulatus. Journal of Applied Aquaculture, https://doi.org/10.1080/10454438.2016.1272031.

Mroz, Z., Jongbloed, A.W., Partanen, K.H., Vreman, K., Kemme, P.A., \& Kogut, J. (2000). The effects of calcium benzoate in diets with or without organic acids on dietary buffering capacity, apparent digestibility, retention of nutrients, and manure characteristics in swine. Journal of Animal Science, 78, 2622-2632. https://doi.org/10.2527/2000.78102622x.

Naseem, M.Z., Khan, S.H., \& Yousaf, M. (2006). Effect of feeding various levels of canola meal on the performance of broiler chicks. Journal of Animal and Plant Sciences, 16, 75-78.

Nourmohammadi, R., Hosseini, S. M., Farhangfar, H. \& Bashtani, M. (2012). Effect of citric acid and phytase enzyme on ileal digestibility of some nutrients in broiler chicks fed on corn-soybean meal diets. Italian Journal of Animal Science, 11. 36-40. doi:org/ 10.4081/2326.

NRC. (2011). Nutrient Requirements of Fish and Shrimp. Washington, DC: The National Academies Press.

Papatryphon, E., Howell, R.A. \& Soares, J.H. (1999). Growth and mineral absorption by striped bass, Morone saxatilis fed a plant feedstuff-based diet supplemented with phytase. Journal of World Aquaculture Society, 30, 161173.

https://doi.org/10.1111/j.1749-7345.1999.tb00863.x.

Pham, M.A., Lee, K.J., Dang, T.M., Lim, S.J., Eo, G.Y.K.J. \& Oh, D.H. (2008). Improved apparent digestibility coefficient of protein and phosphorus by supplementation of microbial phytase in diets containing cottonseed and soybean meal for juvenile olive flounder (Paralichthys olivaceus). Asia-Australasian Journal of Animal Science, 9, 1367-1375. doi:10.5713/AJAS.2008.80053.

Phromkunthong, W., Nuntapong, N. \& Gabaudan, J. (2010). Interaction of phytase ronozyme and citric acid on utilization of phosphorous by Common carp (Cyprinus carpio). Songklanakarin Journal of Science and Technology, 32, 545-547. https://doi.org/20113177842.

Ravindran, V. \& Kornegay, E.T. (1993). Acidification of weaner pig diets: A review. Journal of Science Food and Agriculture, 62, 313-322. doi:10.1002/jsfa.2740620402.

Rodehutscord M. \& Pfeffer E. (1995). Effects of supplemental microbial phytase on phosphorus digestibility and utilization in rainbow trout (Oncorhynchus mykiss). Water Science and Technology, 31, 143-7. https://doi.org/10.1080/17450399509381841.

Rowland, S.J. \& Ingram, B.A. (1991). Diseases of Australian native fishes. In Fisheries Bulletin 4 NSW Fisheries, Sydney, NSW, Australia.

Sakata, T., Adachi, M., Hashida, M., \& Sato, W. (1995). Effects of $n$-butyric acid on epithelial cell proliferation of pig colonic muca in short-term culture. Dtsch Tierartztl Wochenschr, 102, 163-164. PMID: 7555697.

Sari, M., Onol, A.G., Daskiran, M. \& Cengiz, O. (2012). Egg production and calcium-phosphorus utilization of laying hens fed diets supplement with phytase alone or in combination with organic acid. International Journal of Poultry and Science, 11, 181-189. https://doi.org/10.3923/ijps.2012.181.189.

Sarker, M.S.A., Satoh, S., Kamata, K., Haga, Y., \& Yamamoto, Y. (2012). Partial replacement of fish meal with plant protein sources using organic acids to practical diets for juvenile yellowtail, Seriola quinque radiata. Aquaculture Nutrition, 18, 81-89. https://doi.org/10.1111/j.13652095.2011.00880.x.

Sarker, S.A., Satoh, S. \& Kiron, V. (2005). Supplementation of citric acid and amino acid-chelated trace element to develop environment-friendly feed for red sea bream, 
Pagrus major. Aquaculture, 248, 3-11. https://doi.org/10.1016/j.aquaculture.2005.04.012.

Schafer, A., Kopp, W.M., Meyer- Burgdorff, K.H. \& Gqnther, K.D. (1995). Effect of microbial phytase on the utilization of native phosphorus by carp in a diet based on soybean meal. Water Science and Technology, 31, 149-155. https://doi.org/10.2166/wst.1995.0372.

Shah, S.Z.H., Afzal, M., Khan, S.Y., Hussain, S.M. \& Habib, R.Z. (2015a). Prospects of using citric acid as fish feed supplement. Journal of Agriculture \& Biology, 17, 1-8.

Shah, S.Z.H., Fatima, M. \& Hussain, S.M. (2015b). Effect of citric acid and phytase on growth performance and mineralization of Labeo rohita juveniles fed soybean meal-based diet. International Journal of Agriculture \& Biology. http://www.fspublishers.org.

Simons, P.C.M., Versteegh, H.A.J., Jongbloed, A.W., Kemme, P.A., Slump, P., Bos, K.D., Wolters, W.G.E., Beudeker, R.F. \& Verschoor, G.J. (1990). Improvement of phosphorus availability by microbial phytase in broilers and pigs. British Journal of Nutrition, 64, 525-540. https://doi.org/10.1079/bjn19900052.

Tayyab, K., Afzal, M., Iqbal, M., Arshad, A., Aslam, S. \& Batool, M. (2017). Enhanced digestibility of phytase treated canola meal-based diet for Labeo rohita fingerlings. The Journal of Animal and Plant Sciences, 27, 1386-1393.

Usmani, N. \& Jafri, A.K. (2002). Influence of dietary phytic acid on the growth, conversion efficiency and carcass composition of Cirrhinus mrigala $(\mathrm{H})$ fry. Journal of World Aquaculture Society, 33, 199-204.

https://doi.org/10.1111/j.1749-7345.2002.tb00495.x.

Vielma, J., Lall, S.P., Koskela, J., Shooner, F.J. \& Mattila, P.
(1998). Effect of dietary phytase and cholecalciferol on phosphorus bioavailability in rainbow trout, (Oncorhynchus mykiss). Aquaculture, 163, 309-323.

Yi Z., Kornegay, E.T. \& Denbow, D.M. (1996). Effect of microbial phytase on nitrogen and amino acid digestibility and nitrogen retention of turkey poults fed corn-soybean meal diets. Poultry Science, 75, 979-990. https://doi.org/10.3382/ps.0750979.

Yoo, G., Wang, X., Choi, S., Han, K., Kang, J.C. \& Bai, S.C. (2005). Dietary microbial phytase increased the phosphorus digestibility in juvenile Korean rockfish, Sebastes schlegeli fed diets containing soybean meal. Aquaculture, 243, 315- 322 https://doi.org/10.1016/j.aquaculture.2004.10.025.

Zhou, Q.C., Tan, B.P., Mai, K.S. \& Liu, Y.J. (2004). Apparent digestibility of selected feed ingredients for juvenile cobia Rachycentron canadum. Aquaculture, 241, 441451. https://doi.org/10.1016/j.aquaculture.2004.08.044.

Zhu, Y., Ding, Q., Chan, J., Chen, P., \& Wang, C. (2015). The effect of concurrent supplementation of dietary phytase, citric acid and vitamin D3 on growth and mineral utilization in juvenile yellow cat fish Pelteobagrus fulvidraco. Aquaculture, 436, 143-150. doi. org/10.1016/j.aquaculture.2014.11.006.Zyla, K., Ledoux, D.R., Garcia, A. \& Veum, T.L. (1995). An in vitro procedure for studying enzymic dephosphorylation of phytate in maize-soybean feeds for turkey poults. British Journal of Nutrition, 74, 3-17.

https://doi.org/org/10.1079/BJN19950102. 